\title{
KETERPADUAN BLOK TUNJUNGAN DALAM KONTEKS PERENCANAAN KOTA YANG IDEAL
}

\author{
Bramasta Putra Redyantanu \\ Prodi Arsitektur Fakultas Teknik Sipil dan Perencanaan, Universitas Kristen Petra \\ bramasta@petra.ac.id
}

\begin{abstract}
ABSTRAK
Penataan kota ideal merupakan sebuah indikasi dari proses perencanaan yang matang. Dalam tahap perencanaan, terjadi proses simulasi segala macam elemen kota agar dapat sinergi dan berkaitan erat antara satu dan lainnya. Tunjungan, sebagai salah satu blok kota yang membentuk citra kota Surabaya, merupakan sebuah hasil tatanan yang berkembang paling dinamis. Kesenjangan antara penataan ideal dengan kondisi nyata lapangan tidak dapat dihindari. Hal ini salah satunya muncul akibat pengembangan yang dilakukan secara parsial di kawasan tersebut. Studi ini merupakan studi identifikasi kesenjangan keterpaduan antara elemen perencanaan ideal yang diharapkan oleh perencana, terhadap penataan nyata di lapangan. Dari proses identifikasi tersebut ditemukan elemen penataan kota mana yang paling berpotensi untuk dibenahi. Sehingga pada akhirnya akan didapatkan arahan untuk pengembangan Blok Tunjungan yang lebih sinergi dengan tujuan perencanaan awal.
\end{abstract}

Kata kunci: Penataan kota, Keterpaduan elemen kota

\begin{abstract}
The good city is an indication of good process of urban planning. In the planning phase, there is a simulation process about how all kinds of urban elements are related, and also have good synergistic between one another. Tunjungan, as one of the city blocks that formed the image of Surabaya, is an example of dynamic development. The big gap between ideal arrangement and real conditions can not be avoided. Partial development of it is one of the reason. This study is the identification of the gap between good city condition that expected by the planners, against the real condition in the field. The result will show which urban elements are lacking, but potentially can be fixed. The final findings are some guidance to develop Tunjungan block more synergy with the purpose of initial planning.
\end{abstract}

Keywords: Urban planning, Alignment of urban elements

\section{Pendahuluan}

Tunjungan, salah satu kawasan yang sangat kental dengan kota Surabaya, telah melalui banyak sekali fase perkembangan. Daerah ini awalnya direncanakan sebagai pehubung antara Surabaya Utara dan Selatan. Namun sejalan dengan perkembangan kehidupan kota, karakter komersil yang kemudian muncul ke permukaan, sehingga menjadikan Tunjungan sebagai salah satu destinasi belanja kota. Namun kini kondisi tersebut cenderung kembali ke karakter daerah perlintasan semata. Hal ini dikarenakan kegiatan wisata belanja telah bergeser dari kondisi shopping street beralih ke shopping mall. Peralihan ini juga menjadi sebuah indikator nyata adanya pengembangan yang bersifat parsial, tak lagi menyeluruh. Kegiatan kota yang awalnya tersebar sepanjang koridor jalan, kini hanya terkonsentrasi di beberapa titik tertentu saja, semisal 
Tunjungan Plaza. Sedangkan bagian lain dari Tunjungan kemudian cenderung terlupakan. Hal ini tak dapat dihindari, mengingat pemilik modal dan pemerintah kota juga sangat terbatas dalam mengelola lahan berdasarkan hak kepemilikan.

Fenomena di atas seringkali diistilahkan sebagai lost space (Trancik Roger, 1986) ${ }^{1}$. Sebuah istilah yang dipakai untuk menggambarkan kondisi bagian ruang kota yang kemudian gagal untuk beradaptasi dengan perkembangan kehidupan kota. Dalam konteks perencanaan kota yang ideal, dapat dipahami bahwa keberhasilan sebuah penataan adalah di mana setiap elemen kota dapat berfungsi maksimal, kemudian dapat mudah terbaca sebagai sebuah bentuk kepaduan yang menjadi identitas kota (Kevin Lynch, 1960) ${ }^{2}$. Jalur, simpul, penanda, batas, dan distrik adalah peran yang harus dapat muncul dari elemen elemen ruang kota, sehingga sebuah kota dapat terbaca dengan sangat ideal. Kondisi keterpaduan yang kolektif ini akan diidentifikasi sejauh mana penyimpangannya terhadap kondisi nyata di lapangan. Hasilnya adalah temuan elemen kota mana yang kemudian paling berpotensi untuk dibenahi dalam konteks mencapai kondisi yang ideal sesuai perencanaan.

\section{Bahan dan Metode}

Studi ini merupakan studi kualitatif. Identifikasi kondisi lapangan dan studi kajian arahan rencana pengembangan merupakan acuan yang dipakai dalam melihat ketimpangan di antaranya. Proses identifikasi akan dibagi dalam 8 elemen ruang kota (Hamid Shirvani, 1985)3. Area studi sendiri terbatasi dalam blok terbatas, dengan harapan dapat menjadi percontohan dalam studi serupa pada kawasan lainnya. Area blok segitiga Tunjungan sendiri dipilih pada blok segitiga seperti yang terlihat pada Gambar 1. Dasar penentuan baasan ini adalah karena secara morfologi kota, blok segitiga ini merupakan titik pertemuan, serta dikelilingi oleh kondisi tapak tapak yang disparitasnya sangat jauh di antaranya.

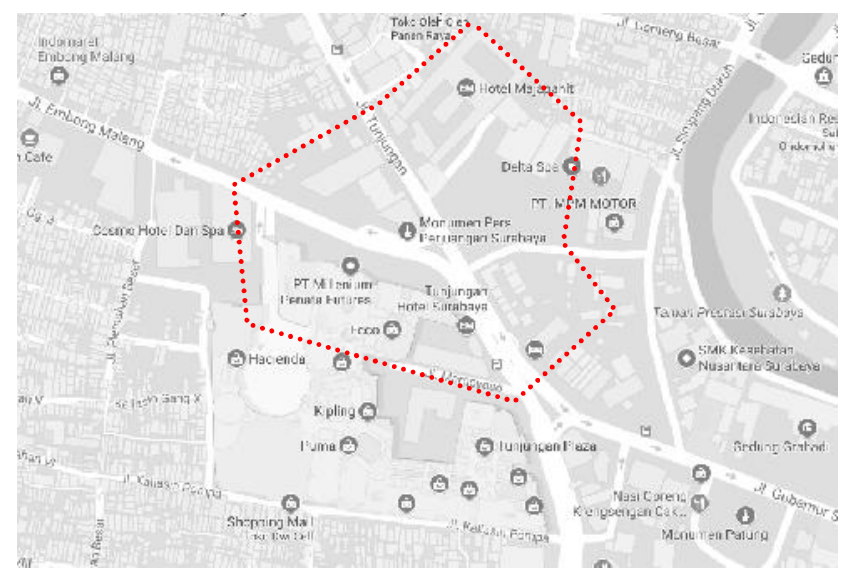

Gambar 1. Batasan area studi blok Tunjungan (Sumber: Peta Google Online, 2017)

\subsection{Kerangka Studi}

Studi diawali dengan melihat teori yang menjadi landasan penataan kota yang ideal. Teori tersebut dipakai dalam menentukan parameter yang akan dipakai dalam proses indetifikasi lapangan. Sebagai referensi, kajian kesejarahan Tunjungan beserta kajian Rencana Tata Ruang Tunjungan akan digunakan sebagai dasar menentukan kondisi ketimpangan keterpaduan, saat disandingkan dengan data nyata dari 
indentifikasi lapangan. Dari komparasi kondisi nyata lapangan dengan kondisi ideal perencanaan, dicapai sebuah paparan kondisi ketimpangannya. Kemudian sebagai penutup, disajikan sebuah arahan umum untuk pengembangan Tunjungan selanjutnya di masa mendatang. Kerangka studi secara visual dapat dilihat pada Gambar 2.
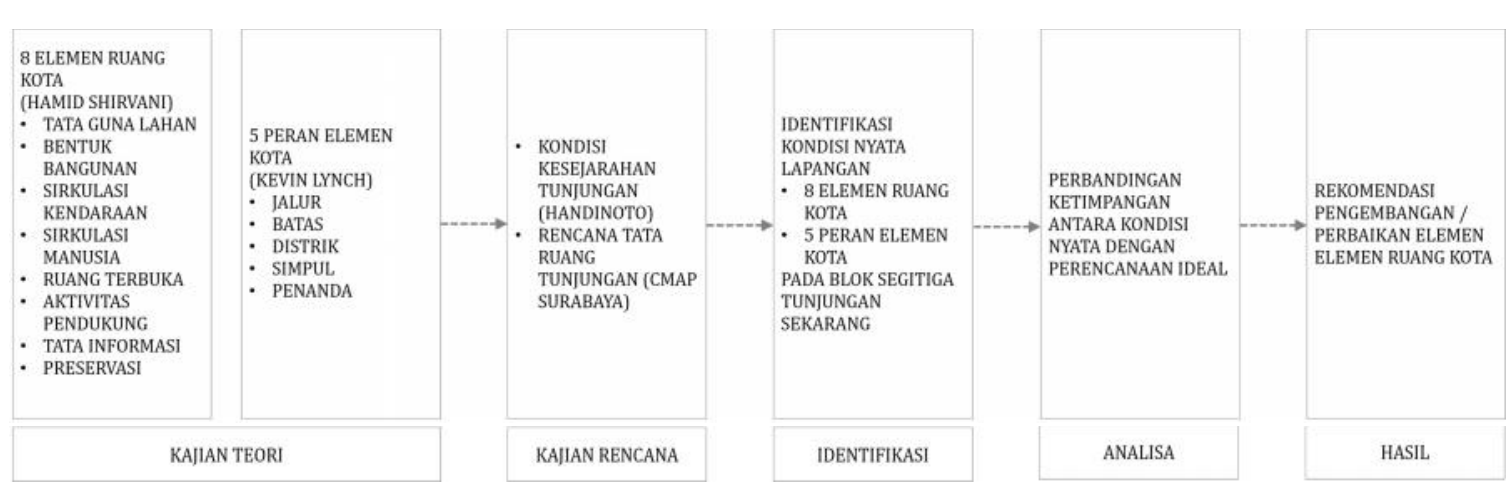

Gambar 2. Kerangka studi indetifikasi

(Sumber: Olahan Pribadi, 2017)

\subsection{Kajian Teori}

Terdapat setidaknya 8 elemen dalam perancangan sebuah ruang kota (Hamid Shirvani, 1985) ${ }^{3}$. Keseluruhannya akan terkait satu dan lainnya, dan direncanakan dengan harapan membawa keterpaduan dalam sebuah kondisi ruang kota. Elemen kota ini merupakan parameter yang diidentifikasi serta disandingkan dengan kajian penataan, sehingga dapat terlihat jelas ketimpangan dari keterpaduannya. Lihat Gambar 3.

1. Tata Guna Lahan Merupakan sistem pengaturan 2 dimensi dalam bentuk peta berwarna. Setiap warna akan mewakili tipe pemanfaatan lahan, serta dapat kemudian diatur persebarannya agar tercapai keseimbangan.

2. Bentuk Bangunan

Parameter ini mengacu pada seberapa besar bangunan terhadap lahan yang tersedia. Gsb, Kdb, Klb, dan sebagainya, adalah sekian dari angka angka yang dapat membatasi komposisi bangunan dalam sebuah ruang kota.

3. Sirkulasi Kendaraan

Kehidupan kota tidak lepas dari perpindahan yang dinamis. Salah satu yang kemudian menjadi krusial di perkotaan adalah kendaraan. Baik pribadi ataupun massal, kendaraan haruslah direncanakan alur pergerakannya agar tidak menimbulkan kekacauan.

4. Pergerakan Manusia

Kota yang baik adalah di mana setiap fasilitas terdekat dapat dijangkau dengan jalan kaki yang nyaman. Akses manusia baik berupa pedestrian, jembatan penyebrangan dan sebagainya, merupakan elemen utama yang wajib untuk dipertimbangkan.

5. Ruang Terbuka

Keseimbangan antara bangunan dan ruang terbuka sangatlah penting. Aktivitas luar ruang, taman, area resapan, penghijauan dan sebagainya merupakan sekian banyak nilai positif dari keberadaan ruang terbuka.

6. Aktivitas Pendukung

Merupakan segala jenis aktivitas yang berlangsung di luar ruangan. Kehidupan kota tidak hanya terjadi pada bangunan semata, melainkan pada ruang ruang 
publik terbuka. Diharapkan dengan adanya aktiitas pendukung, kehidupan sebuah ruang kota dapat menjadikan kota itu semakin hidup.

7. Tata Informasi

Sistem penanda dapat membantu pengguna untuk mengidentifikasi arah gerak, tipe fasilitas, dan sebagainya. Oleh karena itu, elemen ini merupakan elemen yang cukup penting, mengingat banyaknya dan rumitnya sebuah ruang kota komersil yang kompleks.

8. Preservasi Konservasi

Merupakan sebuah upaya menjaga karakter asli dari sebuah ruang kota. Menjaga sebuah kondisi asli ini, dapat terjadi pada bangunan, aktivitas, ruang terbuka, pola jalan, dan sebagainya.

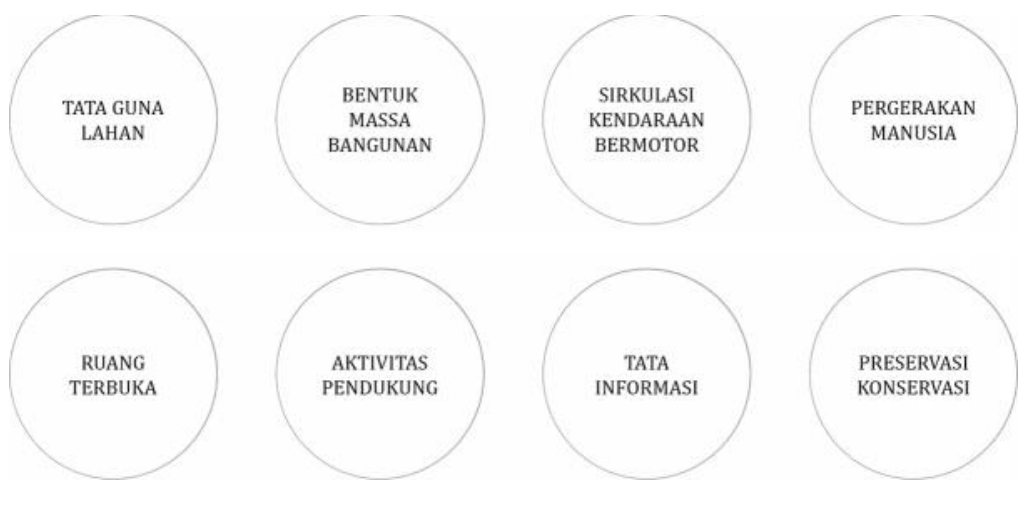

Gambar 3. Parameter elemen elemen indentifikasi lapangan

(Sumber: Olahan Pribadi, 2017)

Elemen elemen kota di atas, dapat secara bersamaan berfungsi membentuk sebuah keterpaduan. Hal ini dapat dilihat dengan menganalisa peran masing masing elemen. Setidaknya terdapat 5 peran utama yang diharapkan hadir dalam sebuah ruang kota yang ideal (Markus Zahnd, 1999) ${ }^{2}$. Peran peran ini akan secara kolektif membentuk identitas sebuah ruang kota mikro, bahkan skala makro sekalipun. Lihat Gambar 4.

1. Jalur

Merupakan peran pergerakan, di mana peran ini umumnya ditemukan pada elemen sirkulasi manusia, ataupun sirkulasi kendaraan.

2. Batas

Merupakan bagian yang menandai teritori sebuah kawasan, terhadap kawasan lainnya. Bagian ini dapat berupa jalan, bangunan, ruang terbuka, dan sebagainya. Fungsinya secara umum dapat menyatukan ataupun membagi wilayah.

3. Distrik

Kesamaan karakter baik fungsi maupun visual dapat dengan mudah menjadikan sebuah blok ruang kota teridentifikasi. Karakter distrik komersial, kawasan permukiman dan sebagainya, merupakan hal yang kemudian akan sangat terkait dengan elemen tata guna lahan.

4. Simpul

Merupakan titik pertemuan strategis perkotaan. Peran ini dapat diambil oleh persimpangan pergerakan, sebuah bangunan pojok, ruang terbuka yang besar, dan sebagainya.

5. Penanda

Merupakan elemen yang paling mencolok, yang kemudian menjadi penanda sebuah daerah. Kondisi kontras dengan sekitar tidak selalu berdampak negatif, namun dapat juga berperan menegaskan fitur utama dari sebuah blok kota. 

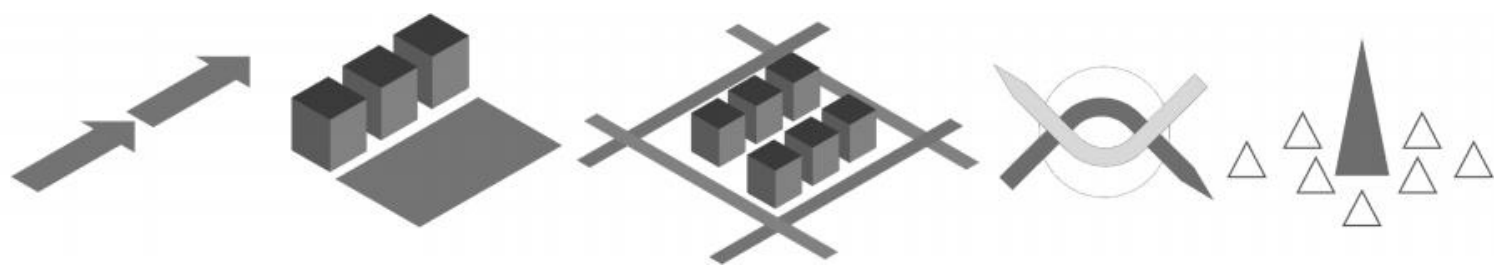

Gambar 4. Peran elemen penyusun ruang kota

(Sumber: Olahan Pribadi dari Kevin Lynch 1960, 2017)

\subsection{Kajian Kesejarahan Tunjungan}

Tunjungan awalnya adalah area perlintasan yang berkembang menjadi area komersial. Namun kini kembali lagi menjadi area perlintasan semata, dengan tujuan pada titik titik tertentu. Periode perkembangan Tunjungan sendiri secara umum terbagi dalam 6 periode waktu (Handinoto, 1996) ${ }^{4}$. Lihat Gambar 5.

1. Periode 1870-1905, Tunjungan sangat dipengaruhi tren arsitektur Neo Klasik. Gaya terapan yang ada pada Tunjungan seringkali diistilahkan Empire Style, dengan ciri atap curam, ekspos kolom, dan kesan klasik pada tampilannya.

2. Periode 1906-1920, dominasi langgam arsitektur terfokus pada gaya Indische. Cirinya adalah bentukan plastis, elemen skluptural, bentukan kubah serta material yang kental dengan warna asli.

3. Periode 1920-1940, merupakan era di mana gaya Destijl mewabah menjadi tren dunia. Istilah yang sering dipakai adalah New Bouwen, dengan ciri minimalis, repetisi kental pada fasade, warna warna tunggal, serta minim dekorasi.

4. Periode 1941-1945 \& 1946-1970, merupakan era stagnasi pra dan pasca kemerdekaan Indonesia.

5. Periode 1970-1990, merupakan periode di mana modernitas dan fungsi menjadi hal utama. Fungsi komersial didominasi oleh tampak tempelan bidang komersial yang menunjukkan identitas dari komoditas yang diperdagangkan.

6. Periode 1990 - kini, merupakan era terkini yang di mana pengembangan mengarah pada sistem blok. Penyatuan fungsi, dimensi bangunan yang besar, merupakan ciri dari periode ini.
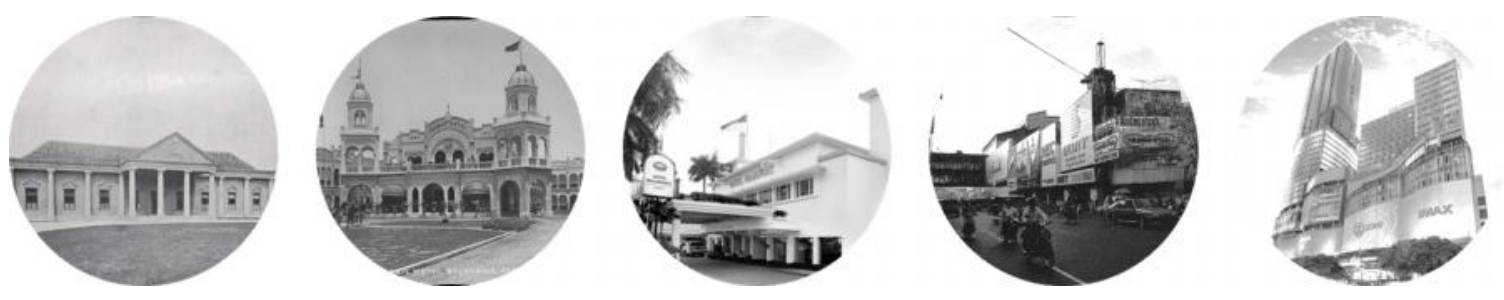

Gambar 5. Periode perkembangan langgam arsitektur pada blok Tunjungan

(Sumber: Olahan Pribadi, 2017)

\subsection{Kajian Rencana Tata Ruang}

Rencana Tata Ruang Kota Surabaya dapat dengan mudah diakses oleh masyarakat secara online. Secara umum, Tunjungan merupakan blok komersial yang didominasi dengan perunutukan perdangangan jasa. Berikut adalah kondisi perencanaan pada kawasan blok Tunjungan. Lihat Gambar 6. 


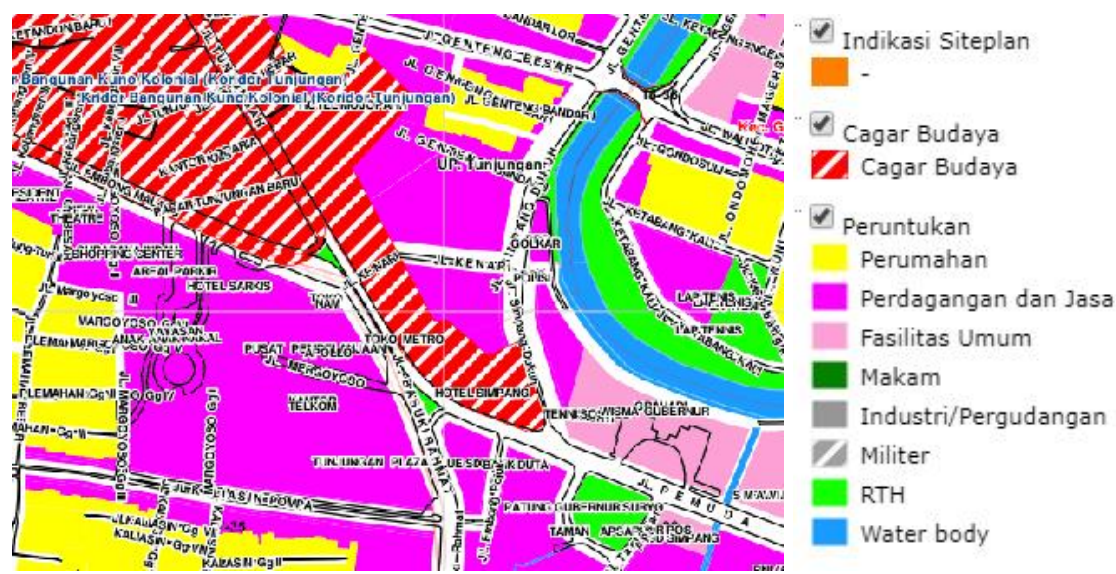

Gambar 6. Rencana Tata Ruang Tunjungan 2017

(Sumber: Peta C Map Surabaya,, 2017)

Area Tunjungan didominasi oleh area berwarna merah (cagar budaya), di mana bangunan yang ada di area itu merupakan pertokoan shopping street, hotel Majapahit dan Gedung BPN. Dominasi lain adalah area perdagangan jasa berwarna ungu, di mana bangunan yang paling dominan adalah kompleks blok Tunjungan Plaza.

\section{Hasil dan Diskusi}

\subsection{Indentifikasi Lapangan}

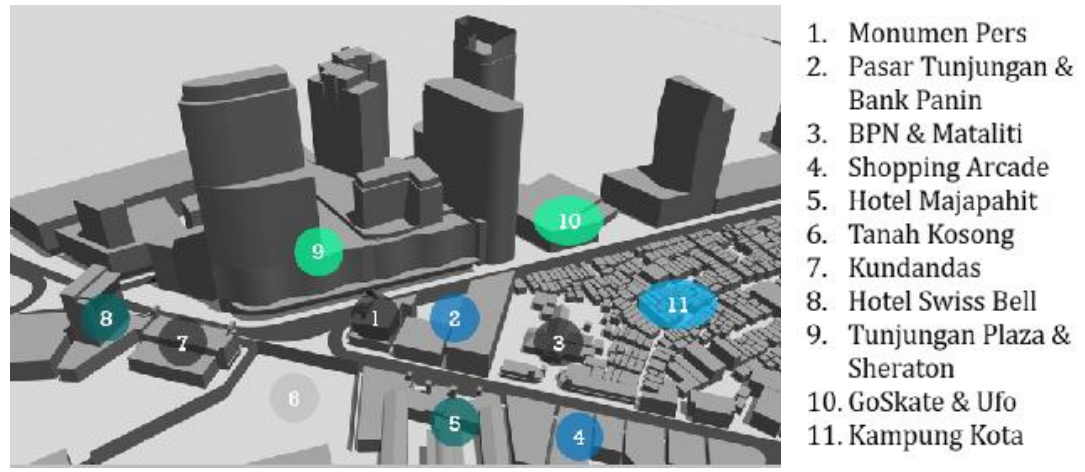

Gambar 7. Tata letak elemen elemen penting pada blok studi (Sumber: Penulis, 2017)

Dapat terlihat dari Gambar 7 di atas, bahwa dominasi blok Tunjungan adalah fungsi perdagangan jasa, di mana terdapat juga selipan bangunan peninggalan sejarah yang memiliki kondisi arsitektur yang cukup khas seperti yang dipaparkan sebelumnya. Berikut adalah hasil indentifikasi berdasarkan parameter elemen kota,

1. Tata Guna Lahan

Seperti yang terlihat pada gambar 8 di bawah, kondisi yang direncanakan didominasi bangunan perdagangan jasa. Peruntukan guna lahan sebagian besar sudah tepat, karena proses mendirikan bangunan di Surabaya sudah melalui proses review oleh tenaga ahli. Namun kondisinya, belum sepenuhnya maksimal sesuai dengan yang diimpikan pada perencanaan. Salah satunya adalah KLB yang diharapkan merata membentuk kompleks bangunan tinggi, baru hanya pada tapak blok Tunjungan Plaza saja yang tercapai. 

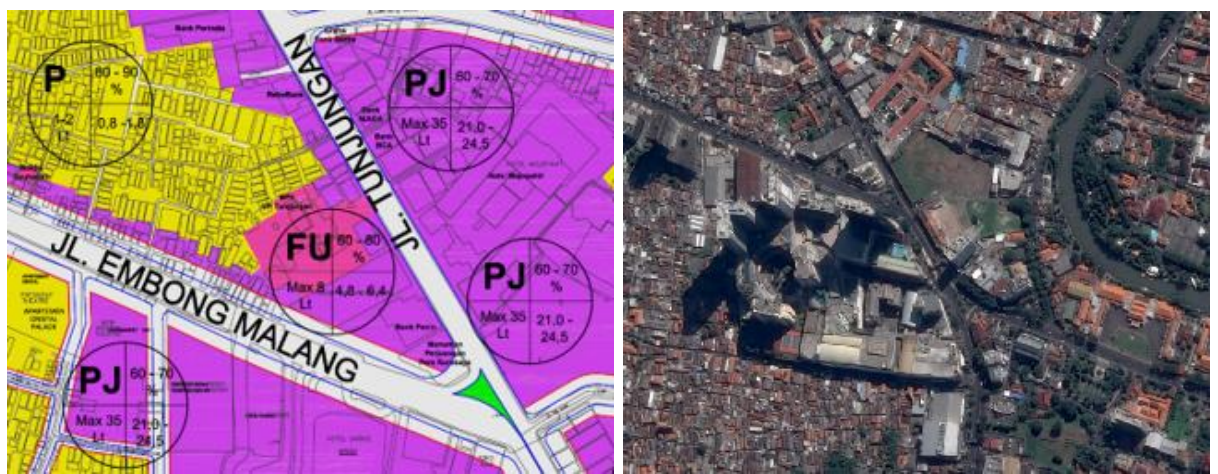

Gambar 8. Tata guna lahan dibandingkan dengan kondisi lapangan

(Sumber: Peta Guna Lahan dan Peta Satelit Google, 2017)

2. Bentuk Bangunan

Bentuk bangunan didominasi oleh beberapa peninggalan sejarah dengan langgam dan visualnya. Namun beberapa objek juga sudah didesain mengikuti kebutuhan terkini dengan dominasi material modern seperti kaca, baja, dan sebagainya. Berikut visual bangunan banguna yang dominan mengisi blok segitiga Tunjungan, terlihat pada Gambar 9.
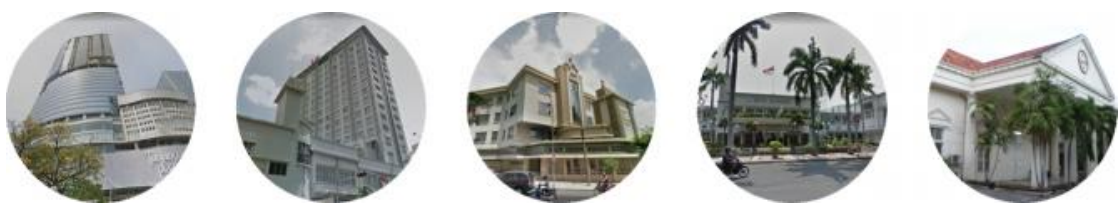

Gambar 9. Kondisi visual arsitektur yang mendominasi Tunjungan (Sumber: Foto Jalan Google, 2017)

3. Sirkulasi Parkir

Kendaraan didominasi jalan satu arah utara pada jalan Embong Malang dan satu arah selatan pada jalan Tunjungan. Area parkir terdapat pada beberapa area terbuka serta pada gedung gedung parkir di tiap fasilitas. Parkir di sisi jalan terjadi hanya pada jalan Tunjungan saja. Lihat Gambar 10.
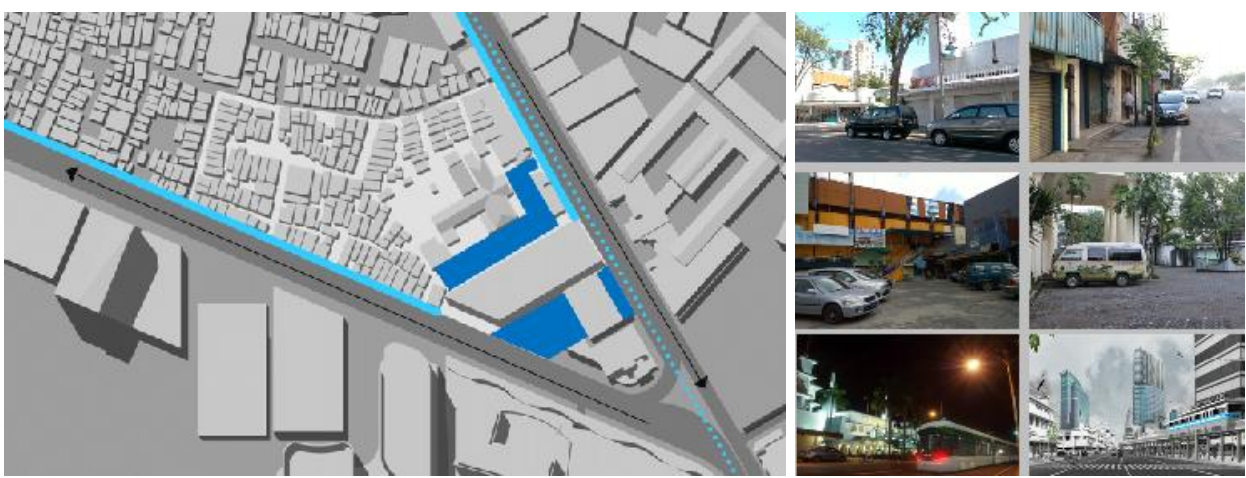

Gambar 10. Sirkulasi kendaraan dan area parkir

(Sumber: Penulis, 2017)

4. Sirkulasi Manusia

Jalur sirkulasi pergerakan orang diakomodasi dengan kondisi pedestrian yang sangat layak. Hanya pada sisi kanan jalan Embong Malang, tahapan perbaikan masih berlangsung, dan butuh untuk diseimbangkan dengan kondisi yang sudah baik di sisi lainnya. Lihat Gambar 11. 

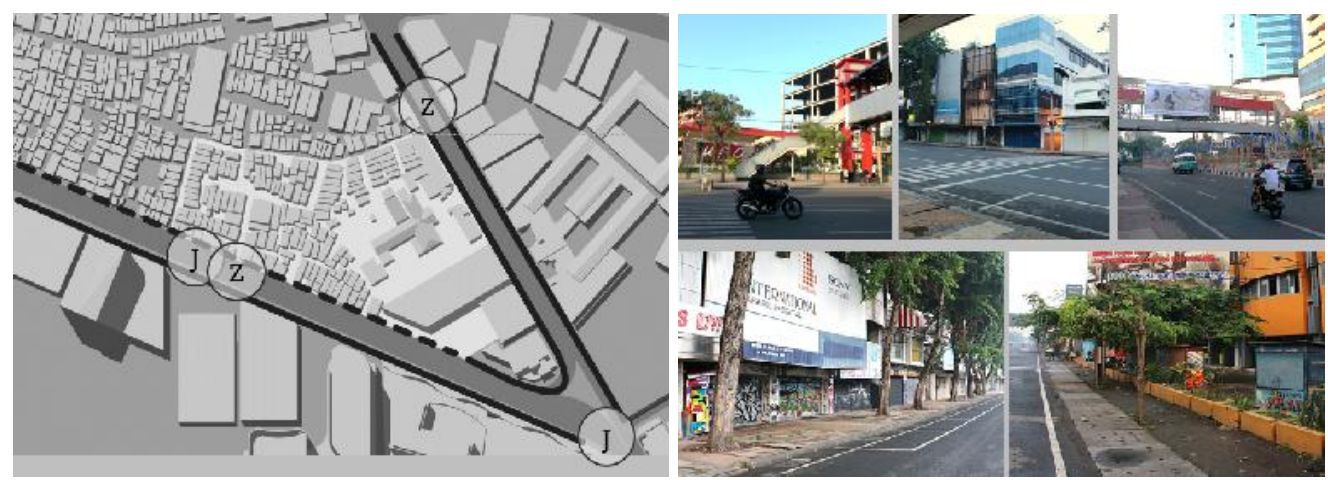

Gambar 11. Jembatan penyebrangan, zebra cross, dan pedestrian

(Sumber: Penulis, 2017)

5. Ruang Terbuka

Terdapat setidaknya area kosong sementara yang belum termanfaatkan menjadi area terbuka. Namun kondisi taman ideal belum dapat dicapai maksimal. Karena sebagian besar dimanfaatkan untuk kegiatan parkir kendaraan. Taman hijau ideal baru ada pada sebatas pulau pulau jalan pengarah pergerakan. Lihat Gambar 12.
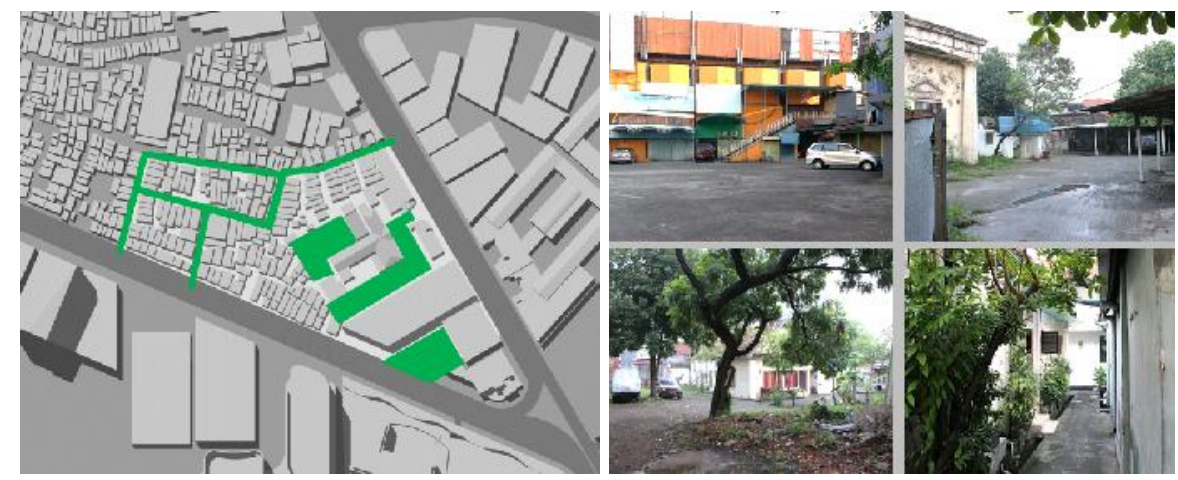

Gambar 12. Kondisi area ruang terbuka di Tunjungan

(Sumber: Penulis, 2017)

6. Aktivitas Pendukung

Tunjungan sangat kental dengan aktivitas tematik luar ruang. Berbagai acara besar melangsungkan pagelarannya pada area ini. Secara regular, terdapat hari bebas kendaraan setiap akhir minggu, di mana pengisinya adalah kegiatan dengan dominasi manusia. Lihat Gambar 13.
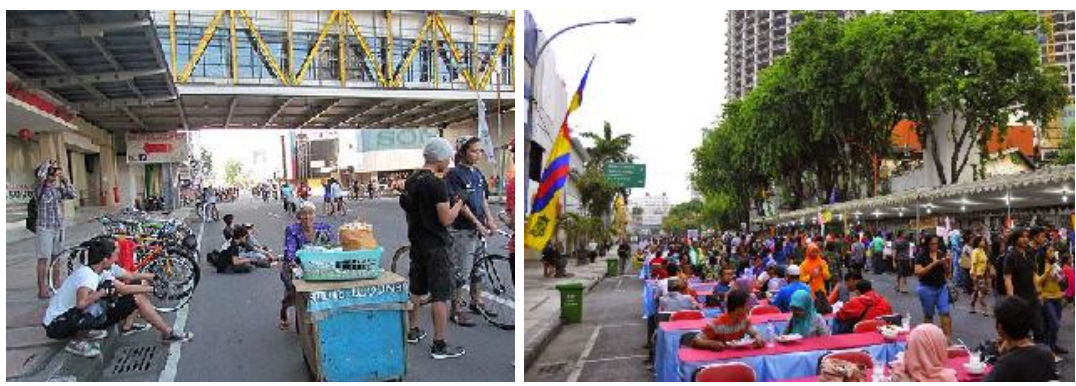

Gambar 13. Aktivitas pendukung tematik di Tunjungan

7. Tata Informasi

(Sumber: Foto Google, 2017)

Sebagai kawasan yang diperuntukkan untuk didominasi oleh peruntukan perdagangan jasa, sistem tata informasi pada kawasan Tunjungan didominasi 
oleh papan papan reklame. Terdapat setidaknya 2 jenis penempatan, terpisah dan tergabung dengan fasade bangunan. Lihat Gambar 14.
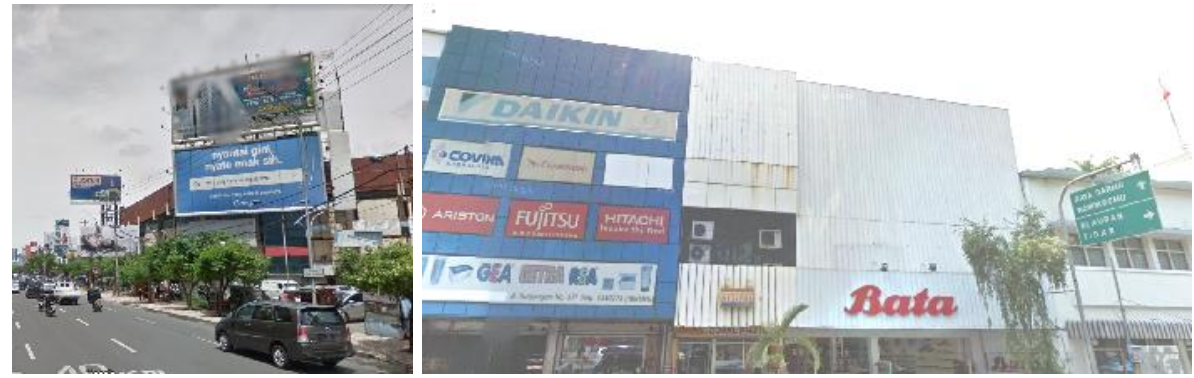

Gambar 14. Sistem tata informasi yang terpisah dan menyatu

8. Preservasi Konservasi

(Sumber: Foto Google, 2017)

Karakter Tunjungan yang khas dengan bangunan peninggalan masa kolonial, menyebabkan dominasi objek preservasi yang dijaga kondisinya adalah bangunan bangunan tersebut. Setidaknya terdapat beberapa bangunan kolonial dengan kondisi yang masih sangat baik. Hotel Majapahit, Monumen Pers Perjuangan, Gedung BPN, dan sebagainya. Selain itu, kondisi yang coba dipreservasi menurut pengamatan adalah kondisi Tunjungan sebagai area 'mlaku mlaku'. Sehingga keberadaan pedestrian dengan toko di kanan kirinya termasuk salah satu bagian yang dijaga keberlanjutannya. Lihat Gambar 15.

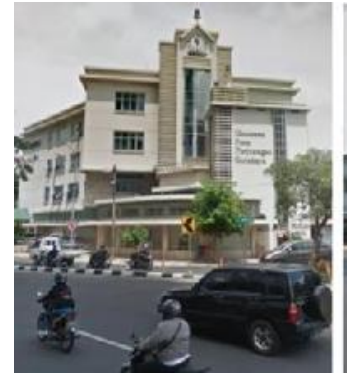

Gambar 15. Preservasi dan konservasi di Tunjungan

(Sumber: Foto Google, 2017)

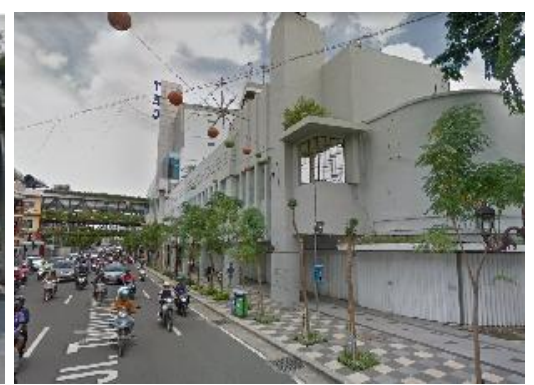

\subsection{Tabel perbandingan}

Berikut adalah perbandingan hasil indentifikasi lapangan dengan kondisi perencanaan yang ideal. Selain itu juga dapat disimpulkan beberapa kondisi peran identitas keterpaduan masing masing elemen ruang kota. Terlihat pada tabel berikut.

\begin{tabular}{llll}
\hline 5 Peran & Kondisi Lapangan & Potensi \\
\hline Jalur & Jalan Tunjungan dan Embong Malang & Perkuatan elemen pedestrian untuk jalur skala manusia \\
\cline { 2 - 3 } Batas & $\begin{array}{l}\text { Jembatan Penyebrangan dan Percabangan } \\
\text { Jalur }\end{array}$ & $\begin{array}{l}\text { Arahan untuk bangunan bangunan yang komposisinya } \\
\text { membentuk gerbang untuk batas dalam skala makro }\end{array}$ \\
\hline Distrik & $\begin{array}{l}\text { Dominasi fungsi peruntukan perdagangan } \\
\text { jasa (komersial) }\end{array}$ & $\begin{array}{l}\text { Penyesuaian fungsi untuk mendukung karakter komersial pada } \\
\text { lahan lahan yang belum dikembangkan }\end{array}$ \\
\hline Penanda & Monumen Pers Perjuangan \&Taman Jalan & $\begin{array}{l}\text { Perkuatan secara visual dengan taman taman tematik pada } \\
\text { taman nodes }\end{array}$ \\
\hline
\end{tabular}

Tabel 1. Peran keterpaduan elemen ruang kota 


\begin{tabular}{|c|c|c|c|}
\hline 8 Elemen & Kondisi Lapangan & Analisa & Saran dan Potensi \\
\hline $\begin{array}{l}\text { Tata Guna } \\
\text { Lahan }\end{array}$ & Komersial dan Fasum & $\begin{array}{l}\text { Sesuai dengan perencanaan } \\
\text { (PADU) }\end{array}$ & $\begin{array}{l}\text { Fungsi BPN bisa } \\
\text { diberdayakan lebih } \\
\text { komersial agar lebih hidup }\end{array}$ \\
\hline $\begin{array}{l}\text { Bentuk } \\
\text { Bangunan }\end{array}$ & $\begin{array}{l}\text { Komposisi Modern dan } \\
\text { Kolonial New Bouwen }\end{array}$ & $\begin{array}{l}\text { Membentuk karakter } \\
\text { Tunjungan dengan kuat } \\
\text { (PADU) }\end{array}$ & $\begin{array}{l}\text { Bangunan baru yang akan } \\
\text { muncul mengambil ide dari } \\
\text { eksisting agar harmonis }\end{array}$ \\
\hline $\begin{array}{l}\text { Sirkulasi } \\
\text { Kendaraan }\end{array}$ & $\begin{array}{l}\text { Jalan } 1 \text { arah, parkir pada } \\
\text { tiap tapak }\end{array}$ & $\begin{array}{l}\text { Lebar memadahi, parkir } \\
\text { komunal masih minim } \\
\text { (KURANG PADU) }\end{array}$ & $\begin{array}{l}\text { Pemanfaatan lahan untuk } \\
\text { parkir komunal, } \\
\text { memungkinkan pergerakan } \\
\text { manusia }\end{array}$ \\
\hline $\begin{array}{l}\text { Sirkulasi } \\
\text { Manusia }\end{array}$ & $\begin{array}{l}\text { Fisik pedestrian lebar dan } \\
\text { ideal }\end{array}$ & $\begin{array}{l}\text { Kondisi pedestrian yang } \\
\text { ideal belum menyeluruh } \\
\text { (HAMPIR PADU) }\end{array}$ & $\begin{array}{l}\text { Idealisasi pedestrian } \\
\text { keseluruhan dan tambahan } \\
\text { spot spot penyebrangan }\end{array}$ \\
\hline $\begin{array}{l}\text { Ruang } \\
\text { Terbuka }\end{array}$ & $\begin{array}{l}\text { Proporsi ruang terbuka } \\
\text { cukup memenuhi } \\
\text { persyaratan }\end{array}$ & $\begin{array}{l}\text { Ruang terbuka yang ada } \\
\text { adalah lahan sisa (KURANG } \\
\text { PADU) }\end{array}$ & $\begin{array}{l}\text { Pemanfaatan lahan terbuka } \\
\text { untuk keperluan publik dan } \\
\text { penghijauan, sehingga } \\
\text { menjadi ruang terbuka aktif }\end{array}$ \\
\hline $\begin{array}{l}\text { Aktivitas } \\
\text { Pendukung }\end{array}$ & $\begin{array}{l}\text { Bersifat perayaan pada } \\
\text { ruang jalan }\end{array}$ & $\begin{array}{l}\text { Cukup ramai pada saat } \\
\text { perayaan namun sepi saat } \\
\text { jalan kembali menjadi fungsi } \\
\text { sirkulasi (HAMPIR PADU) }\end{array}$ & $\begin{array}{l}\text { Tambahan fitur pada } \\
\text { pedestrian yang memacu } \\
\text { masyarakat untuk berjalan } \\
\text { kaki, serta aktivitas ruang } \\
\text { luar yang bersifat reguler }\end{array}$ \\
\hline Tata Informasi & $\begin{array}{l}\text { Didominasi media iklan } \\
\text { raksasa menutupi } \\
\text { bangunan }\end{array}$ & $\begin{array}{l}\text { Beberapa area mati } \\
\text { dimanfaatkan untuk area } \\
\text { iklan dengan menghiraukan } \\
\text { aspek arsitektural (KURANG } \\
\text { PADU) }\end{array}$ & $\begin{array}{l}\text { Penataan komposisi media } \\
\text { iklan agar lebih padu, } \\
\text { terintegrasi, tidak terkesan } \\
\text { asal tempel pada bangunan } \\
\text { mangkrak }\end{array}$ \\
\hline Preservasi & $\begin{array}{l}\text { Bangunan cagar budaya : } \\
\text { monument pers, hotel } \\
\text { majapahit, eks kundandas, } \\
\text { gedung BPN }\end{array}$ & $\begin{array}{l}\text { Beberapa bangunan cagar } \\
\text { budaya terjaga sangat baik } \\
\text { namun yang lain } \\
\text { terbengkalai (PADU) }\end{array}$ & $\begin{array}{l}\text { Potensi restorasi bangunan } \\
\text { bangunan kuno terbengkalai } \\
\text { untuk memperkuat karakter } \\
\text { Tunjungan }\end{array}$ \\
\hline
\end{tabular}

Tabel 2. Identifikasi elemen dan keterpaduan perencanaan dan kondisi lapangan

\section{Simpulan}

Keterpaduan elemen arsitektur ruang kota pada Blok Tunjungan mayoritas sudah terpenuhi. Hal ini terlihat dengan adanya setiap elemen pada kondisi nyata di lapangan, walau belum sepenuhnya ideal. Secara umum, beberapa elemen yang berpotensi untuk dipadukan lebih ideal antara lain : 
- SIRKULASI DAN PARKIR KENDARAAN : masih memanfaatkan badan jalan, ruang ruang terbuka. Sebaiknya diadakan sebuah gedung parkir komunal, sehingga pergerakan orang lebih dapat terasa perpindahannya dari satu tempat ke tempat lain, memanfaatkan pedestrian yang ada

- SIRKULASI MANUSIA : kondisi pedestrian sangat ideal di beberapa sisi, namun di sisi lain belum terselesaikan. Namun melihat tren yang ada, perbaikan secara menyeluruh bisa dikatakan dalam proses yang jelas.

- RUANG TERBUKA : kondisi ruang terbuka praktis hanya untuk kebutuhan parkir. Bagian minor yang sudah ideal penghijauannya pun hanya sebatas taman pembatas jalan. Beberapa tapak memiliki potensi untuk dikembangkan menjadi ruang hijau yang aktif.

- AKTIVITAS PENDUKUNG : aktivitas pendukung jalan Tunjungan sudah sangat beragam, namun belum regular. Perlu sebuah kegiatan luar ruang yang dapat diakomodasi sepanjang waktu, sehingga kawasan menjadi lebih hidup.

- TATA INFORMASI : Tata kelola yang baik belum dapat menyeluruh pada setiap bagian. Bagian yang terdapat pada fasade Tunjungan Plaza dirasa cukup ideal dan terintegrasi. Sebaliknya, papan reklame dan informasi pada gedung gedung mangkrak cenderung bersifat tempelan tanpa desain yang jelas.

Sedangkan jika ditinjau dari keterpaduan yang sudah berjalan maksimal, berikut adalah elemen elemen ruang kota yang padu :

- TATA GUNA LAHAN : elemen ini cenderung paling mudah untuk dibuat padu antara perencanaan dan kondisi nyata lapangan. Sebab setiap pembangunan harus melalui review dari pemerintah kota.

- BENTUK BANGUNAN : sebagai salah satu kawasan cagar budaya, segala bentuk arsitektur yang muncul di Tunjungan, terlebih dahulu melewati review oleh tim cagar budaya. Maka dari itu, tidak sulit untuk mewujudkan keterpaduan serta identitas visual kawasan komersil kolonial.

- PRESERVASI KONSERVASI : seperti yang disebutkan sebelumnya, bangunan bangunan kolonial peninggalan belanda, mayoritas berada pada kondisi yang cukup layak, bahkan beberapa sangat layak, seperti Hotel Majapahit, Monumen Pers. Keberlanjutan yang perlu dijaga untuk meneruskan identitas Tunjungan yang sudah melekat pada karakter kawasan cagar budaya.

Upaya dari pemerintah untuk memadukan secara sinergi antara perencanaan dan pembangunan sebetulnya sudah sangat terasa. Terlihat dari perencanaan ruang kota yang sangat mengakomodasi hal tersebut. Hanya saja perlu upaya lebih untuk dapat lebih membuat kondisi sekarang dapat berlanjut ke masa mendatang.

\section{Ucapan Terima Kasih}

Terima kasih kami ucapkan kepada Tim Jurnal RUAS Universitas Brawijaya yang telah mengakomodasi publikasi studi ini.

\section{Daftar Pustaka}

Handinoto. 1996. Perkembangan Kota dan Arsitektur Kolonial Belanda di Surabaya, 1870 1940. Surabaya : UK Petra Surabaya

Hamid, S. 1985. The Urban Design Process. New York: Van Nostrand Reinhold.

Lynch, K. 1960. The Image of The City. USA: The MIT Press.

Trancik, R. 1986. Finding Lost Space : Theories of Urban Design. New York: Architectural Press.

Zahnd, M. 1999. Perancangan Kota Secara Terpadu. Yogyakarta: Kanisius. 